\title{
Lead exposure may affect gingival health in children
}

\author{
Borany Tort ${ }^{1}$, Youn-Hee Choi ${ }^{{ }^{*}}$ (D, Eun-Kyong Kim², Yun-Sook Jung ${ }^{1}$, Mina Ha ${ }^{3}$, Keun-Bae Song ${ }^{1}$ and Young-Eun Lee
}

\begin{abstract}
Background: Several studies have reported the harmful effects of lead poisoning. However, the relationship between lead exposure and oral health of children has not been well defined. The aim of this study was to investigate the relationship between blood lead level (BLL) and oral health status of children.

Methods: A total of 351 children (aged 7-15 years) were recruited from the pilot data of the Korean Environmental Health Survey in Children and Adolescents, which was designed to examine environmental exposure and children's health status in South Korea. Blood samples were taken to determine BLLs and oral examinations were performed to assess oral health parameters, including community periodontal index (CPI), gingival index (GI), and plaque index (PI). Information regarding socioeconomic status, oral hygiene behavior, and dietary habits was collected from parents and guardians.

Results: The participants were divided equally into four quartiles, with quartile I comprised of children with the lowest BLLs. There were significant differences for PI $(p<0.05)$ among the quartile groups. Using logistic regression models, we found a significant relationship between BLL and oral health parameters. The crude odds ratios for $\mathrm{CPI}, \mathrm{Gl}$, and PI in the third quartile were 5.24 (95\% Cl: 1.48-18.56), 4.35 (95\% Cl: 1.36-13.9), and 4.17 (95\% Cl: 1.50-11.54), respectively, while the age and gender-adjusted odds ratios were 7.66 (95\% Cl: 1.84-31.91), 6.80 (95\% Cl: 1.80-25.68), and 3.41 (95\% Cl: 1.12-10.40), respectively. After adjustments for age, gender, parent education level, and frequency of tooth brushing, the adjusted odds ratios were 7.21 (95\% Cl: 1.72-30.19), 6.13 (95\% Cl: 1.62-23.19), and 3.37 (95\% Cl: 1.10-10.34), respectively.
\end{abstract}

Conclusions: A high BLL might be associated with oral health problems in children, including plaque deposition and gingival diseases.

Keywords: Gingivitis, Pathology, Oral hygiene

\section{Background}

Lead is a heavy metal widely employed in automobiles, gasoline, lubricants, and decolorizing agents, including other applications such as agriculture as an insecticide [1]. In the medical field, lead is used to produce antifungal agents and provide radiation protection [2]. However, reports of symptoms of lead poisoning are common and have been known since at least the second century B.C, with such poisoning in lead industrial workers and children first reported in the nineteenth century [3].

The detrimental effects of lead poisoning are related to the amount of lead accumulated in the body and blood lead level (BLL) is considered to be associated

\footnotetext{
* Correspondence: cyh1001@knu.ac.kr

${ }^{1}$ Department of Preventive Dentistry, School of Dentistry, Kyungpook

National University, 2177 Dalgubeol-daero, Jung-gu, Daegu 700-412, Republic of Korea

Full list of author information is available at the end of the article
}

with physical health, mental health, the immune system, and functional growth [4]. Also, lead exposure has been reported to have an impact on human intelligence and social behavior, with life-long adverse effects $[5,6]$.

In addition to these general health risks, lead exposure can have harmful effects on oral health. Such exposure can affect enamel formation leading to caries production, delayed dental enamel formation, worsened dental fluorosis, and periodontal bone loss, as well as increased tooth loss in men [7-14]. A study by Saraiva et al. found that BLL was significantly associated with periodontal health in adult participants [15]. Another study conducted with Thai children living in a shipyard industrial area showed that there was a significantly positive correlation between high BLL and periodontal problems, including the presence of deep pockets, particularly teeth 16 and 46 [16]. 
Children tend to absorb more lead into their bodies than adults because of a higher rate of metabolism as well as a physical tendency to inhale lead from polluted air. Moreover, child gastrointestinal organs seem to absorb lead more easily [17]. Although some studies have speculated regarding a possible relationship between BLL and dental caries in children [18, 19], few have assessed the association between BLL and periodontal status in child subjects. The aim of present study was to investigate the relationship between BLL and oral health status in Korean children.

\section{Methods}

\section{Study population}

A total of 351 children ranging from 7 to 15 years old living in two cities in South Korea (Incheon city and Cheonan city) were recruited from the participants of the pilot study of the Korean Environmental Health Survey in Children and Adolescents [20]. That study aimed to show the environmental exposure and health of Korean children who were sampled with a national representativeness by use of a questionnaire survey, clinical tests, and physical examinations in 2011 and 2012. Of 351 subjects, 137 agreed to participate, were undertook oral health examination, and included in this study. The present study was approved by the institutional review board of a university hospital (IRB No. DKUH 2012-10003-001). Parents or guardians of the subjects provided written informed consent for their participation, and completed questionnaires regarding their socioeconomic status and the oral hygiene behaviors of their children.

\section{Measurement of blood lead levels}

Whole blood (3-5 ml) was drawn from the subjects and sealed in a heparin containing tube. Lead levels were determined using atomic absorption spectrophotometry (800 Zeeman correction; Spectral AA, Varian, NSW, Australia) at a commercial laboratory. The coefficient of variation of the blood lead measurements was $4.9 \%$.

\section{Oral health examinations}

Oral health examinations were conducted by 1 dentist and 2 dental hygienists trained according to the World Health Organization (WHO) guidelines on oral health surveys [21]. The dentist performed oral examinations using a dental mirror and periodontal probe under artificial light with the subject in a portable dental chair in order to detect decayed, missing, and filled surfaces of permanent teeth (DMFT), and also determined community periodontal index (CPI), gingival index (GI), and plaque index (PI) values [21-24]. The CPI, GI, and PI values of teeth $11,16,26,31,36$, and 46 were assessed in the present study. CPI was scored as follows: 0 (healthy), 1 (bleeding following probing), 2 (presence of dental calculus). Because the presence of dental calculus is not an indicator of periodontal health in children, 11 participants whose CPI scores of six representative teeth were only 0 and 2 were excluded in the analysis for CPI. Also participants whose one of CPI scores of six representative teeth was 1 regardless of the rest were classified as having CPI score of 1 . Given that children scarcely have periodontitis and are likely to have pseudo-periodontal pockets due to tooth eruption, CPI scores of 3 and 4 were not used.

\section{Socioeconomic status and oral hygiene behavior}

Information regarding potential covariates was obtained from questionnaires completed by parents and guardians. We surveyed socioeconomic variables including family income, parent education level, father and mother's occupations, oral hygiene behaviors such as frequency of tooth cleaning and frequency of intake of sugar-containing sweets, dental treatment demands, and history of decayed teeth.

\section{Statistical analysis}

The subjects were divided into 4 equal quartiles based on measured BLL, with quartile I comprised of children with the lowest BLLs. Analysis of variance (ANOVA) and a Chi-square test were used to compare the covariates and oral health parameters among the quartiles. One crude and two adjusted logistic regression models were used to explore the relationship between BLL and oral health parameters. Two adjusted odds ratios (OR) were calculated.

The first model adjusted for age and gender, and the other added parent education level, and frequency of tooth brushing additionally as confounders. SPSS (ver. 20.0, IBM, NY, USA) was utilized for the analyses, with statistical significance considered at $p<0.05$.

\section{Results}

Table 1 shows the average measured BLLs according to demographic characteristics, socioeconomic status, oral hygiene behavior, dietary habits, and clinical oral parameters. The mean age of the subjects was $10.9 \pm 2.1$ years and 69 were girls (50.4\%). Overall mean BLL was $1.25 \pm$ $0.43 \mu \mathrm{g} / \mathrm{dl}$, ranging from 0.36 to $2.90 \mu \mathrm{g} / \mathrm{dl}$. There were no statistically significant differences observed among those factors.

Table 2 shows the distribution of demographic characteristics, socioeconomic status, oral health behavior, and dietary habits of the subjects after dividing into the BLL quartiles. Based on measured BLL, the study population was divided into equal quartile groups (I, II, III, and IV), with quartile I composed of subjects with the lowest BLLs. There were no statistically significant differences observed among the quartile groups. 
Table 1 Mean blood lead level according to socioeconomic status and oral hygiene behavior in school-age children

\begin{tabular}{|c|c|c|}
\hline & $\mathrm{N}$ & $\begin{array}{l}\mathrm{Pb}(\mu \mathrm{g} / \mathrm{dl}) \\
\text { Mean } \pm \mathrm{SD}\end{array}$ \\
\hline Total participants & 137 & $1.25 \pm 0.43$ \\
\hline \multicolumn{3}{|l|}{ Grade } \\
\hline Elementary & 100 & $1.35 \pm 0.43$ \\
\hline Middle & 37 & $0.99 \pm 0.32$ \\
\hline \multicolumn{3}{|l|}{ Gender } \\
\hline Male & 68 & $1.33 \pm 0.43$ \\
\hline Female & 69 & $1.19 \pm 0.43$ \\
\hline \multicolumn{3}{|c|}{ Family income $\left(\times 10,000\right.$ won/month) ${ }^{a}$} \\
\hline$<200$ & 17 & $1.18 \pm 0.38$ \\
\hline 200-399 & 47 & $1.20 \pm 0.36$ \\
\hline $400-599$ & 46 & $1.31 \pm 0.46$ \\
\hline$>600$ & 23 & $1.25 \pm 0.52$ \\
\hline \multicolumn{3}{|c|}{ Level of parent's education ${ }^{a}$} \\
\hline$\leq$ High school & 61 & $1.29 \pm 0.39$ \\
\hline College/university & 70 & $1.22 \pm 0.48$ \\
\hline Graduate school & 5 & $1.22 \pm 0.17$ \\
\hline \multicolumn{3}{|l|}{ Father's occupation } \\
\hline Professional & 17 & $1.18 \pm 0.38$ \\
\hline White collar/service & 47 & $1.20 \pm 0.36$ \\
\hline Blue collar & 46 & $1.31 \pm 0.46$ \\
\hline Unemployed & 23 & $1.25 \pm 0.52$ \\
\hline \multicolumn{3}{|l|}{ Mother's occupation } \\
\hline Professional & 24 & $1.31 \pm 0.50$ \\
\hline White collar/service & 39 & $1.23 \pm 0.42$ \\
\hline Blue collar & 11 & $1.21 \pm 0.34$ \\
\hline Unemployed & 63 & $1.23 \pm 0.40$ \\
\hline \multicolumn{3}{|c|}{ Frequency of tooth cleaning } \\
\hline$\leq$ once a day & 3 & $1.20 \pm 0.12$ \\
\hline 2-3 times/day & 101 & $1.29 \pm 0.44$ \\
\hline$>4$ times/day & 33 & $1.17 \pm 0.40$ \\
\hline \multicolumn{3}{|c|}{ Intake of sugar-containing sweets } \\
\hline$<$ Once a day & 23 & $1.26 \pm 0.40$ \\
\hline Once a day & 71 & $1.25 \pm 0.44$ \\
\hline 2-3 times/day & 43 & $1.27 \pm 0.45$ \\
\hline \multicolumn{3}{|c|}{ Dental treatment demand (1 year) } \\
\hline Yes & 80 & $1.27 \pm 0.45$ \\
\hline No & 56 & $1.23 \pm 0.41$ \\
\hline \multicolumn{3}{|l|}{ History of decayed teeth } \\
\hline Yes & 63 & $1.31 \pm 0.40$ \\
\hline No & 74 & $1.21 \pm 0.46$ \\
\hline \multicolumn{3}{|l|}{ CPI index } \\
\hline 0 & 34 & $1.19 \pm 0.39$ \\
\hline$\geq 1$ & 92 & $1.29 \pm 0.44$ \\
\hline
\end{tabular}

Table 1 Mean blood lead level according to socioeconomic status and oral hygiene behavior in school-age children (Continued)

\begin{tabular}{lll}
\hline & $\mathrm{N}$ & $\begin{array}{c}\mathrm{Pb}(\mu \mathrm{g} / \mathrm{dl}) \\
\text { Mean } \pm \mathrm{SD}\end{array}$ \\
\hline $\begin{array}{l}\text { Gingival index } \\
\leq 1\end{array}$ & 39 & $1.20 \pm 0.41$ \\
$2-3$ & 98 & $1.28 \pm 0.44$ \\
Plaque index & & \\
$\quad \leq 2$ & 56 & $1.15 \pm 0.46$ \\
3 & 81 & $1.33 \pm 0.40$ \\
\hline $\begin{array}{l}\text { Abbreviations: } P b \text { lead } \\
\text { aSome answers were missing }\end{array}$ & &
\end{tabular}

Distribution of oral health parameters according to the BLL quartiles is shown in Table 3. Participants with a higher BLL were more likely to have a high PI value $(p<0.015)$. There were no other statistically significant differences.

Results of logistic regression analysis for the association between BLL and oral health parameters are shown in Table 4. A significant association was found in the third quartile between BLL and all oral health parameters. Subjects quartile III had a crude OR of 5.24 (95\% CI: 1.48-18.56), 4.35 (95\% CI: 1.36-13.9), and 4.17 (95\% CI: 1.50-11.54) for CPI, GI, and PI, respectively, while those in the fourth quartile had a crude OR of 3. 14 [95\% CI: 1.14-8.41] for PI.

We constructed an age and gender adjusted model, which showed that subjects in the third quartile had an OR of 7.66 (95\% CI: 1.84-31.91), 6.80 (95\% CI: 1.80-25. 68), and 3.41 (95\% CI: 1.12-10.40) for CPI, GI, and PI, respectively, while those in the second quartile had an OR of 3.29 [95\% CI: 1.06-10.19] for GI.

Finally, following adjustments for age, gender, parent education level, and frequency of tooth brushing, subjects in the third quartile had an OR of 7.21 (95\% CI: 1. 72-30.19), 6.13 (95\% CI: 1.62-23.19), and 3.37 (95\% CI: 1.10-10.34) for CPI, GI, and PI respectively, while those in the second quartile had an OR of 3.44 [95\% CI: 1.0011.90] and 3.58 [95\% CI: 1.12-11.40] for CPI and GI, respectively.

\section{Discussion}

The aim of the present study was to investigate the relationship between BLL and oral health in children. We recruited subjects from participants in the CHEER study, a national representative study performed in Korea that focused on the influence of living environment on the well-being of children. We found that higher BLLs were positively correlated with worse oral health measurements, including CPI, GI, and PI. Furthermore, in logistic regression analysis, that effect was maintained after adjusting for age, gender, parent education level, and frequency of tooth brushing. 
Table 2 Distribution of demographic characteristics, socioeconomic status, oral health behavior, and dietary habits of children according to blood lead level quartiles

\begin{tabular}{|c|c|c|c|c|c|}
\hline & $\begin{array}{l}\text { Total } \\
(n=137)\end{array}$ & $\begin{array}{l}\text { Quartile I } \\
(n=35)\end{array}$ & $\begin{array}{l}\text { Quartile II } \\
(n=34)\end{array}$ & $\begin{array}{l}\text { Quartile III } \\
(n=34)\end{array}$ & $\begin{array}{l}\text { Quartile IV } \\
(n=34)\end{array}$ \\
\hline & No. (\%) & No. (\%) & No. (\%) & No. (\%) & No. (\%) \\
\hline Age (years, mean $\pm S D$ ) & $10.9 \pm 2.1$ & $12.4 \pm 1.7$ & $11.1 \pm 2.1$ & $10.2 \pm 1.9$ & $9.8 \pm 1.8$ \\
\hline \multicolumn{6}{|l|}{ Gender } \\
\hline Male & 68 (49.6) & $12(34.3)$ & $17(50.0)$ & $19(55.9)$ & $20(58.8)$ \\
\hline Female & $69(50.4)$ & $23(65.7)$ & $17(50.0)$ & $15(44.1)$ & $14(41.2)$ \\
\hline \multicolumn{6}{|c|}{ Family income (10,000 won/month) ${ }^{a}$} \\
\hline$<200$ & $17(12.8)$ & $4(11.4)$ & $8(24.2)$ & $1(2.9)$ & $4(12.9)$ \\
\hline 200-399 & $47(35.3)$ & $14(40.0)$ & $11(33.3)$ & $14(41.2)$ & $8(25.8)$ \\
\hline $400-599$ & $46(34.6)$ & $9(25.7)$ & $12(36.4)$ & $11(32.4)$ & $14(45.2)$ \\
\hline$>600$ & $23(17.3)$ & $8(22.9)$ & $2(6.1)$ & $8(23.5)$ & $5(16.1)$ \\
\hline \multicolumn{6}{|l|}{ Parent's education ${ }^{a}$} \\
\hline$\leq$ High school & $61(44.9)$ & $11(31.4)$ & $19(55.9)$ & $11(33.3)$ & $20(58.8)$ \\
\hline College/university & $70(51.5)$ & 24() & $13(38.2)$ & $19(57.6)$ & $14(41.2)$ \\
\hline Graduate school & $5(3.7)$ & - & $2(5.9)$ & $3(9.1)$ & - \\
\hline \multicolumn{6}{|l|}{ Father's occupation } \\
\hline Profession & $50(36.5)$ & $10(28.6)$ & $12(35.3)$ & $13(38.2)$ & $15(44.1)$ \\
\hline White collar/Service & $45(32.8)$ & $15(42.9)$ & $8(23.5)$ & $10(29.4)$ & $12(35.3)$ \\
\hline Blue collar & $34(24.8)$ & $8(22.9)$ & $11(32.4)$ & $10(29.4)$ & $5(14.7)$ \\
\hline Unemployed & $8(5.8)$ & $2(5.7)$ & $3(8.8)$ & $1(2.9)$ & $2(5.9)$ \\
\hline \multicolumn{6}{|l|}{ Mother's occupation } \\
\hline Profession & $24(17.5)$ & $6(17.1)$ & $3(8.8)$ & $10(29.4)$ & $5(14.7)$ \\
\hline White collar/Service & $39(28.5)$ & $10(28.6)$ & $8(23.5)$ & $9(26.5)$ & $12(35.3)$ \\
\hline Blue collar & $11(8.0)$ & $1(2.9)$ & $6(17.6)$ & $2(5.9)$ & $2(5.9)$ \\
\hline Unemployed & $63(46.0)$ & $18(51.4)$ & $17(50.0)$ & $13(38.2)$ & $15(44.1)$ \\
\hline \multicolumn{6}{|c|}{ Frequency of tooth cleaning } \\
\hline$\leq$ Once a day & $3(2.2)$ & - & $1(0.7)$ & $2(5.9)$ & - \\
\hline 2-3 times/day & $101(73.7)$ & $25(71.4)$ & $24(17.5)$ & $27(79.4)$ & $25(73.5)$ \\
\hline$>4$ times/day & $33(24.1)$ & $10(28.6)$ & $9(26.5)$ & $5(14.7)$ & $9(26.5)$ \\
\hline \multicolumn{6}{|c|}{ Sugar-containing sweets intake } \\
\hline$<$ Once a day & $23(16.8)$ & $5(14.3)$ & $5(14.7)$ & $7(20.6)$ & $6(17.6)$ \\
\hline Once a day & $71(51.8)$ & $18(51.4)$ & $22(64.7)$ & $16(47.1)$ & $15(44.1)$ \\
\hline 2-3 times/day & $43(31.4)$ & $12(34.3)$ & $7(20.6)$ & $11(32.4)$ & $13(38.2)$ \\
\hline \multicolumn{6}{|c|}{ Dental treatment demand (1 year) } \\
\hline Yes & $80(58.8)$ & $20(57.1)$ & 21 (61.8) & $17(50.0)$ & $22(66.7)$ \\
\hline No & $56(41.2)$ & 15 (42.9) & $13(38.2)$ & $17(50.0)$ & $11(33.3)$ \\
\hline
\end{tabular}

The mean BLL of the children enrolled in this study was $1.25 \pm 0.43 \mu \mathrm{g} / \mathrm{dl}$ and ranged from 0.36 to $2.90 \mu \mathrm{g} /$ $\mathrm{dl}$, which was lower than noted in previous studies conducted in China $(5.56 \mu \mathrm{g} / \mathrm{dL})$ and the United States (2. $30 \mu \mathrm{g} / \mathrm{dL})[19,25]$. However, even with this relatively low concentration of lead, we found evidence of its adverse effects on the oral health of our subjects.
Our results are consistent with those of previous studies of adults. According to a study conducted by El-Said et al. that focused on the risk of gingivitis in lead-exposed workers, gingivitis is related to lead sulfide, a product of the reaction between lead and hydrogen sulfide during food fermentation, which can produce gum irritation [26]. According to their study, the risk of gingivitis in exposed workers 
Table 3 Distribution of oral health parameters according to blood lead level quartiles

\begin{tabular}{|c|c|c|c|c|c|c|}
\hline & $\begin{array}{l}\text { Total } \\
(n=137)\end{array}$ & $\begin{array}{l}\text { Quartile I } \\
(n=35)\end{array}$ & $\begin{array}{l}\text { Quartile II } \\
(n=34)\end{array}$ & $\begin{array}{l}\text { Quartile III } \\
(n=34)\end{array}$ & $\begin{array}{l}\text { Quartile IV } \\
(n=34)\end{array}$ & $P$-value \\
\hline & No. (\%) & No. (\%) & No. (\%) & No. (\%) & No. (\%) & \\
\hline \multicolumn{7}{|c|}{ Presence of dental caries } \\
\hline DMFT (mean \pm SD) & $1.5 \pm 1.9$ & $1.4 \pm 1.5$ & $1.7 \pm 2.3$ & $1.1 \pm 1.5$ & $1.7 \pm 2.1$ & $0.477^{\mathrm{a}}$ \\
\hline \multicolumn{7}{|c|}{$\begin{array}{l}\text { History of dental caries } \\
\text { (DMFT } \geq 1 \text { ) }\end{array}$} \\
\hline Yes & $63(46.0)$ & $11(31.4)$ & $17(50.0)$ & $18(52.9)$ & $17(50.0)$ & $0.252^{*}$ \\
\hline No & $74(54.0)$ & $24(68.6)$ & $17(50.0)$ & $16(47.1)$ & $17(50.0)$ & \\
\hline \multicolumn{7}{|c|}{ Community periodontal index } \\
\hline mean $\pm S D$ & $1.1 \pm 0.8$ & $0.9 \pm 0.8$ & $1.2 \pm 0.7$ & $1.2 \pm 0.7$ & $1.1 \pm 0.8$ & $0.358^{\mathrm{a}}$ \\
\hline 0 & $34(27.8)$ & $13(41.9)$ & $7(23.3)$ & $4(12.1)$ & $10(31.3)$ & 0.083 \\
\hline$\geq 1$ & $92(73.0)$ & $18(58.1)$ & $23(76.7)$ & $29(87.9)$ & $22(68.8)$ & \\
\hline \multicolumn{7}{|l|}{ Gingival index } \\
\hline mean $\pm S D$ & $2.1 \pm 0.9$ & $1.8 \pm 0.9$ & $2.1 \pm 0.8$ & $2.3 \pm 0.7$ & $2.0 \pm 0.9$ & $0.150^{\mathrm{a}}$ \\
\hline$\leq 1$ & $37(28.5)$ & $15(42.9)$ & $8(23.5)$ & $5(14.7)$ & $11(32.4)$ & $0.061^{*}$ \\
\hline $2-3$ & $98(71.5)$ & $20(57.1)$ & $26(76.5)$ & $29(85.3)$ & $23(67.6)$ & \\
\hline \multicolumn{7}{|l|}{ Plaque index } \\
\hline mean $\pm S D$ & $2.6 \pm 0.5$ & $2.4 \pm 0.5$ & $2.6 \pm 0.5$ & $2.7 \pm 0.4$ & $2.7 \pm 0.5$ & $0.015^{\mathrm{a}}$ \\
\hline$\leq 2$ & $56(40.9)$ & $21(60.0)$ & $15(44.1)$ & $9(26.5)$ & 11(32.4) & $0.025^{*}$ \\
\hline 3 & 81 (59.1) & $14(40.0)$ & $19(55.9)$ & $25(73.5)$ & 23 (67.6) & \\
\hline
\end{tabular}

Abbreviations: DMFT decayed/missing/filled surfaces of permanent teeth, CPI community periodontal index, Gl gingival index, $P I$ plaque index

${ }^{*} p$-value obtained from $x^{2}$-test

Data analyzed by ANOVA

Italics are statistically significant $(p<0.05)$

Table 4 Association between blood lead level (quartiles) and oral health parameters

\begin{tabular}{|c|c|c|c|c|c|c|c|}
\hline & & \multicolumn{2}{|c|}{ Model 1} & \multicolumn{2}{|c|}{ Model 2} & \multicolumn{2}{|c|}{ Model 3} \\
\hline & & OR & $95 \% \mathrm{Cl}$ & OR & $95 \% \mathrm{Cl}$ & OR & $95 \% \mathrm{Cl}$ \\
\hline \multicolumn{8}{|c|}{ CPI (outcome) } \\
\hline \multirow[t]{4}{*}{ Lead level } & Quartile I & Ref. & & Ref. & & Ref. & \\
\hline & Quartile II & 2.37 & $0.79-7.18$ & 3.14 & 0.93-10.55 & 3.44 & $1.00-11.90$ \\
\hline & Quartile III & 5.24 & $1.48-18.56$ & 7.66 & $1.84-31.91$ & 7.21 & $1.72-30.19$ \\
\hline & Quartile IV & 1.59 & $0.57-4.47$ & 2.38 & $0.69-8.21$ & 2.65 & $0.75-9.44$ \\
\hline \multicolumn{8}{|c|}{ Gl (outcome) } \\
\hline \multirow[t]{4}{*}{ Leadlevel } & Quartile I & Ref. & & Ref. & & Ref. & \\
\hline & Quartile II & 2.44 & $0.86-6.88$ & 3.29 & $1.06-10.19$ & 3.58 & $1.12-11.40$ \\
\hline & Quartile III & 4.35 & $1.36-1.90$ & 6.80 & $1.80-25.68$ & 6.13 & $1.62-23.19$ \\
\hline & Quartile IV & 1.57 & $0.59-4.19$ & 2.50 & $0.77-8.19$ & 2.81 & $0.83-9.47$ \\
\hline \multicolumn{8}{|c|}{ PI (outcome) } \\
\hline \multirow[t]{4}{*}{ Leadlevel } & Quartile I & Ref. & & Ref. & & Ref. & \\
\hline & Quartile II & 1.90 & $0.73-4.95$ & 1.66 & $0.61-4.52$ & 1.60 & $0.58-.40$ \\
\hline & Quartile III & 4.17 & $1.50-11.54$ & 3.41 & $1.12-10.40$ & 3.37 & $1.10-10.34$ \\
\hline & Quartile IV & 3.14 & $1.14-8.41$ & 2.47 & $0.80-7.60$ & 2.37 & $0.76-7.38$ \\
\hline
\end{tabular}

Model 1: Unadjusted model

Model 2: Model adjusted for age and gender

Model 3: Model adjusted for age, gender, parent education level, and frequency of tooth brushing

Abbreviations: $\mathrm{Cl}$ confidence interval, $C P I$ community periodontal index, $G$ gingival index, $P I$ plaque index, OR odds ratio, Ref reference quartile

Italics are statistically significant $(p<0.05)$ 
was 4.82 times higher than in non-exposed workers. Arora et al. also reported that cumulative lead exposure might increase the risk of tooth loss in adults [14].

Although the biological link between lead exposure and periodontal disease has not been clearly elucidated, an increase in reactive oxygen species (ROS) has been suggested to be a factor, as ROS are generated by lead exposure and known to cause oxidative stress [27]. Lee et al. reported an association between BLL and oxidative stress in adults [28]. ROS can also cause damage to proteins and DNA, as well as lipid peroxidation [29], and an increased level can lead to damage to gingival, periodontal ligament, and alveolar bone tissues [30]. Furthermore, lead in blood has been suggested to disturb the function of the salivary gland, which may contribute to plaque accumulation [31]. For example, heavy metals such as lead imitate calcium in some ways. Therefore lead may interfere with calcium metabolism which can alter normal cell function acutely and perturbation of calcium-metabolism may cause disorder of salivary gland function [32-34]. Available evidences showed that administration of lead resulted in 30-40\% diminishment of salivary flow rates in rats [31]. However, there was no study to support this hypothesis in case of people. These factors might explain the results of our study.

The current study has some limitations. First, since the subjects of our study were recruited from only 2 cities in South Korea, the findings are not representative of the overall Korean population. In addition, since this is a cross-sectional study, the results must be cautiously interpreted because this is not causality but association study. As for another limitation, final sample size was not enough to have statistical power when including several confounders in logistic regression models resulting in non-significant association at the stratum of the fourth quartile. However, this result provides meaningful evidence that relatively higher blood lead in children was associated with poorer gingival health. Despite these limitations, to the best of our knowledge, this is the first epidemiologic study to present results regarding the effects of lead exposure on periodontal health in children in Korea.

\section{Conclusions}

In conclusion, our findings indicate a relationship between BLL and oral health problems in children, especially gingivitis. Because of the adverse effects on oral health, attention must be paid even in cases with a low BLL and strategies devised to lower lead levels in children.

\section{Abbreviations}

ANOVA: Analysis of variance; BLL: Blood lead level; CHEER: Children's Health and Environment Research; CPI: Community periodontal index;

DMFT: Decayed, missing, and filled surfaces of permanent teeth; Gl: Gingival index; OR: Odds ratios; Pl: Plaque index; WHO: World Health Organization

\section{Acknowledgments}

The authors thank Heesun Yang whose institution is department of Public Health, Graduate School of Dankook University for statistical analysis of linearity test. The authors also wish to thank the subjects and their parents for their kind cooperation.

\section{Funding}

This research was supported by Grants-in-Aid for Children's Health and Environment Research from the Ministry of Environment of Korea. This research was supported by Basic Science Research Program through the National Research Foundation of Korea funded by the Ministry of Education (NRF-2016R1D1A3B03934825).

\section{Availability of data and materials}

The data that support this study are available restrictively under control of Ministry of Environment of Korea. Data are however available from the authors upon reasonable request and with permission of Ministry of Environment of Korea.

\section{Authors' contributions}

Authors $\mathrm{YHC}$ and $\mathrm{MH}$ contributed to the design of the study, data interpretation, and manuscript revisions. KBS and YEL gathered the data. YSJ and EKK did statistical analysis. BT drafted the manuscript. All authors read and approved the final manuscript.

\section{Ethics approval and consent to participate}

The present study was approved by the institutional review board of a university hospital (IRB No. DKUH 2012-10-003-001). Parents or guardians of the subjects provided written informed consent for their participation, and completed questionnaires regarding their socioeconomic status and the oral hygiene behaviors of their children.

\section{Competing interests}

The authors declare that they have no competing interests.

\section{Publisher's Note}

Springer Nature remains neutral with regard to jurisdictional claims in published maps and institutional affiliations.

\section{Author details}

'Department of Preventive Dentistry, School of Dentistry, Kyungpook National University, 2177 Dalgubeol-daero, Jung-gu, Daegu 700-412, Republic of Korea. ${ }^{2}$ Department of Dental Hygiene, College of Science and Technology, Kyungpook National University, 386 Gajangdong, Sangju 742-711, Republic of Korea. ${ }^{3}$ Department of Preventive Medicine, Dankook University College of Medicine, 119, Dandae-ro, Dongnam-gu, Cheonan-si, Chungnam 330-714, Republic of Korea. ${ }^{4}$ Department of Dental Hygiene, Daegu Health College, 15 Youngsong-Ro, Buk-Gu, Daegu 702-722, Republic of Korea.

Received: 23 June 2017 Accepted: 27 April 2018

Published online: 04 May 2018

\section{References}

1. Rom WN, Markowitz SB. Environmental and occupational medicine. 4th ed. Philadelphia: Wolters Kluwer/Lippincott Williams \& Wilkins; 2007.

2. Milne GWA. Gardner's commercially important chemicals: synonyms, trade names, and properties. New Jersey: Wiley; 2005.

3. Meyer PA, Brown MJ, Falk H. Global approach to reducing lead exposure and poisoning. Mutat Res. 2008;659:166-75.

4. Craft-Rosenberg M, Pehler SR. Encyclopedia of family health. Los Angeles: SAGE Publications; 2011.

5. Koller K, Brown T, Spurgeon A, Levy L. Recent developments in low-level lead exposure and intellectual impairment in children. Environ Health Perspect. 2004;112:987-94.

6. Ekvall S, Ekvall VK. Pediatric nutrition in chronic diseases and developmental disorders: prevention, assessment, and treatment. USA: Oxford University Press; 2005.

7. Bowen WH. Exposure to metal ions and susceptibility to dental caries. J Dent Educ. 2001;65:1046-53. 
8. Moss ME, Lanphear BP, Auinger P. Association of dental caries and blood lead levels. JAMA. 1999;281:2294-8.

9. Weiss B, Anderson D, Marrs T. Aging and vulnerability to environmental chemicals: age-related disorders and their origins in environmental exposures. Royal Soc Chem. 2012;

10. Whitney E, Rolfes SR. Understanding nutrition. Boston: Cengage Learning; 2007.

11. Gerlach RF, Cury JA, Krug FJ, Line SR. Effect of lead on dental enamel formation. Toxicol. 2002;175:27-34.

12. Leite GA, Sawan RM, Teofilo JM, Porto IM, Sousa FB, Gerlach RF. Exposure to lead exacerbates dental fluorosis. Arch Oral Biol. 2011;56:695-702.

13. Dye BA, Hirsch R, Brody DJ. The relationship between blood lead levels and periodontal bone loss in the United States, 1988-1994. Environ Health Perspect. 2002;110:997-1002.

14. Arora M, Weuve J, Weisskopf MG, Sparrow D, Nie H, Garcia Rl, Hu H. Cumulative lead exposure and tooth loss in men: the normative aging study. Environ Health Perspect. 2009;117:1531-4.

15. Saraiva MC, Taichman RS, Braun T, Nriagu J, Eklund SA, Burt BA. Lead exposure and periodontitis in US adults. J Periodontal Res. 2007;42:45-52.

16. Youravong $\mathrm{N}$, Teanpaisan $\mathrm{R}$. The periodontal health of lead-exposed children living in a shipyard industrial area. Toxicol Ind Health. 2015;31:459-66.

17. American Academy of Pediatrics Committee on Environmental Health. Lead exposure in children: prevention, detection, and management. Pediatr. 2005;116(4):1036

18. Campbell JR, Moss ME, Raubertas RF. The association between caries and childhood lead exposure. Environ Health Perspect. 2000;108:1099.

19. Gemmel A, Tavares M, Alperin S, Soncini J, Daniel D, Dunn J, et al. Blood lead level and dental caries in school-age children. Environ Health Perspect. 2002;110:A625.

20. Ha M, Kwon HJ, Leem JH, Kim HC, Lee KJ, Park I, Lim YW, Lee JH, Kim Y, Seo JH, Hong SJ, Choi YH, Yu J, Kim J, Yu SD, Lee BE. Korean environmental health survey in children and adolescents (KorEHS-C): survey design and pilot study results on selected exposure biomarkers. Int J Hyg Environ Health. 2014:217:260-70.

21. World Health Organization. Oral health surveys: basic methods. 4th ed. Geneva: World Health Organization; 1997.

22. Larmas M. Has dental caries prevalence some connection with caries index values in adults. Caries Res. 2010;44:81-4.

23. Löe $H$. The gingival index, the plaque index and the retention index systems. J Periodontol. 1967;38(Suppl):610-6.

24. Mueller HP. Periodontology: the essentials. Stuttgart: Thieme; 2011.

25. Li MM, Cao J, Xu J, Cai SZ, Shen XM, Yan CH. The national trend of blood lead levels among Chinese children aged 0-18 years old, 1990-2012. Environ Int. 2014;71:109-17.

26. El-Said KF, El-Ghamry AM, Mahdy NH, El-Bestaw NA. Chronic occupational exposure to lead and its impact on oral health. J Egypt Public Health Assoc. 2008:83:451-66.

27. Hsu PC, Liu MY, Hsu CC, Chen LY, Guo YL. Lead exposure causes generation of reactive oxygen species and functional impairment in rat sperm. Toxicol. 1997;122:133-43.

28. Lee DH, Lim JS, Song K, Boo JDR Jr. Graded associations of blood lead and urinary cadmium concentrations with oxidative-stress-related markers in the U.S. population: results from the third National Health and nutrition examination survey. Environ Health Perspect. 2006;114:350-4.

29. Yetkin-Ay Z, Cadir B, Uskun E, Bozkurt FY, Delibas N, Gultepe FM, et al. The periodontal status of indirectly lead-exposed apprentices working in autorepair workshops. Toxicol Ind Health. 2007;23:599-606.

30. Chakraborty S, Tewari S, Sharma RK, Narula SC, Ghalaut PS, Ghalaut V. Impact of iron deficiency anemia on chronic periodontitis and superoxide dismutase activity: a cross-sectional study. J Periodontal Implant Sci. 2014:44:57-64.

31. Watson GE, Davis BA, Raubertas RF, Pearson SK, Bowen WH. Influence of maternal lead ingestion on caries in rat pups. Nat Med. 1997:3:1024-5.

32. Pounds JG. Effect of lead intoxication on calcium homeostasis and calciummedicated cell function. Neurotoxicology. 1984;5:295-332.

33. Simons TJB. Lead-calcium interactions in cellular lead toxicity. Neurotoxicology. 1993;14:77-86.

34. Craan A, Nadon G, P'an AYS. Lead flux through kidney and salivary glands of rats. Am J Phys. 1984;247:F773-83.

\section{Ready to submit your research? Choose BMC and benefit from:}

- fast, convenient online submission

- thorough peer review by experienced researchers in your field

- rapid publication on acceptance

- support for research data, including large and complex data types

- gold Open Access which fosters wider collaboration and increased citations

- maximum visibility for your research: over $100 \mathrm{M}$ website views per year

At BMC, research is always in progress.

Learn more biomedcentral.com/submissions 